\title{
Historical, Morphological and Syntactic Patterns of Tundra Nenets Dual System
}

\author{
Minsong $\mathrm{He}^{1, *}$ \\ ${ }^{1}$ School of European Languages and Cultures, Beijing Foreign Studies University, 100089, Beijing, China. \\ *Email: minsong@bfsu.edu.cn
}

\begin{abstract}
Tundra Nenets is one of a few Uralic languages retained the dual system. A broad range of previous studies on protolanguages, morphology, morphophonology, and syntax of Tundra Nenets are reviewed in this paper, for the purpose of shaping a comprehensive framework of dual number in Tundra Nenets. Both diachronic and synchronic characteristics of dual system are discussed in this paper, where morphological and syntactic patterns of dual number (e.g., nominal declension, verbal inflection, construction of pronouns and dual quantifier agreement) are thoroughly analysed. This paper yields several key findings as following. According to the analysis, the development of dual patterns in Proto-Uralic and Proto-Samoyedic serves as the fundamental factors for the dual system in modern Tundra Nenets. Besides, an analogous but uneven correspondence between dual and plural in terms of various inflections provides evidence for the role of dual as a derivative from plural. Additionally, "dual dilemma" summarised and proposed by this paper refers to the complications that emerge in the alternative syntactic expressions of dual number, revealing different outcomes in certain contexts. Moreover, despite the differences in orthography and diacritics among scholars, there is a relatively undoubted consensus over the real grammatical representations of dual forms in Tundra Nenets. Dialectal differences and pragmatic features of Tundra Nenets dual system await further research. These results shed light on the special status of dual number in Tundra Nenets with a long tradition and the significant function of dual for specifying meanings in morphological and syntactic aspects of this language.
\end{abstract}

Keywords: Dual System, Grammatical Number, Tundra Nenets, Samoyedic.

\section{INTRODUCTION}

\subsection{Tundra Nenets: An Introduction}

Tundra Nenets is the largest and the most wellpreserved Samoyedic language, which belongs to the Uralic language family. Etymologically, the name 'Nenets' comes from nyenecy ${ }^{\circ} h$ 'Nenets; person', which is further related to the gloss $n^{\prime} e n e y^{\circ}$ 'true'; the previous name for Nenets in the last two centuries was 'Yuraks' [1]. The traditional territory of Tundra Nenets stretches from Yenisei delta and Yenisei Bay, Yamal peninsula in the east (Siberian part) to Kanin Peninsula, Malaya Zemlya in the west (European part), which borders Arctic Ocean in the north and extends to the taiga forest in the south (Forest Nenets area). The population of Tundra Nenets speakers is estimated to be around 20,000, which accounts for almost half of all ethnic Nenets people. Because of the heavy russification and low natural growth of the population, Tundra Nenets is widely regarded as an endangered language, especially in the European part of Tundra Nenets area, where almost all speakers have become bilingual along with Russian [2]. Despite the vast territory, Tundra Nenets exhibits few diversity among its dialects, probably attributed to a higher extent of mobility and frequent contact among Nenets from different dialectal zones driven by a nomadic lifestyle of reindeer herding and hunting [1]. There are three main dialectal groups: Western, Central and Eastern (Siberia).

Similar to other Uralic languages, a relatively high level of agglutination is embedded in the morphological pattern of Tundra Nenets [1]. There are a maximum of five morphemes in nominal words (root, derivational affix, possessive suffix, number suffix, case suffix), where no more than seven morphemes can be found in Tundra Nenets verbs (root, derivational suffixes, tense, mood, subject agreement, object agreement). Categories of nominal inflection include number (singular, dual and plural), case (three grammatical cases: nominative, 
accusative, genitive; four local cases: dative, locative, ablative, prosecutive (prolative), and possessive, which contains various person/number affixes. For verbs, the conjugational criteria are subject/object/reflexive agreement (which is closely related with the transitivity and reflexibility of verb), tense (aorist/unmarked, past, future, habitual and future-in-the-past), aspect (perfective and imperfective), mood (18 types: imperative, conjunctive, interrogative, optative, necessitative, probabilitative, obligative, hortative, potential, inferential, etc) [2]. The agglutination of Tundra Nenets is typical but not absolute, since analytical constructions and vague boundaries between suffixes also play an important role in the expression of various grammatical meanings in this language [1]. As for syntax, Tundra Nenets is classified as a rigid headfinal SOV (Subject-Object-Verb) language. Periphrastic clausal negation is constructed with the help of an nonfinite connegative form of a lexical verb and an inflected finite negative verb. Non-finite verbs, including participles, clausal nominalisations (action nominals) and converbs, account for a crucial element in the construction of subordinate clauses. These so-called 'mixed categories' demonstrate verbal properties and one other part of speech, which can be nouns, adjectives, or adverbs.

\subsection{Dual Number}

As one of the grammatical numbers, dual refers to two distinct entities, either objects or persons [3]. When considering all languages that are subject to dual-plural distinction, dual can appear in articles, nominal/adjective declension, verbal conjugation, construction of various kinds of pronouns. Thereinto, the expression for objects or persons that exceeds the amount of one is made more precise by separating the grammatical subcategory denoting two number from the one denoting several entities in general, yielding the coexistence of dual and plural number and restricting the plural as the grammatical number that represents more than two objects or persons. In this process, dual gains its independent status when assigning the property of amount to the morphological pattern of one language, and the semantic representation of 'two things or persons' is emphasised. In others words, dual has been separated from the much more commonly used plural number through a natural, historical process so as to highlight the status of 'two entities' against 'one entity' or 'at least three entities', partly thanks to the existence of paired items (i.e., trousers, eyes) or persons (i.e., couples, twins) in the daily life of human beings. The use of dual may also ease the situation for expression. For example, the meaning of 'two apples' can be conveyed with the dual marker without referring to the numeral word 'two'. Apart from Tundra Nenets, several other Uralic languages also possess such uncommon grammatical number, including all Samoyedic languages (Forest Nenets, Enets, Nganassan, Selkup, Kamas), all Ugric languages except Hungarian (Khanty, Mansi), and Pite Saami [4]. Dual number can be reconstructed in Proto-Uralic and Proto-Samoyedic, though some of its rules remain unattested and with limitations. Dual was also realised in the reconstruction of Proto-Indo-European and was retained in its earliest attested daughter languages. The usage of it, however, has considerably faded and remains present in only a few modern languages [5]. Prominent examples among Indo-European languages that share these morphological characteristics are Ancient Greek, Sanskrit, Gothic, Irish, Lithuanian and Slovene [6]. Other ancient and modern languages with dual number include Egyptian, Classical Arabic, Tagalog, Khoe, Inuktitut, Hmong etc.

This paper will discuss the dual system from the historical, morphology and syntax perspective. The second chapter introduces the use of dual number in Proto-Uralic, Proto-Samoyedic and pre-Proto-Nenets. The third chapter provides a relatively wide range of information about morphological patterns in dual number. The fourth chapter presents syntactic features of dual system, particularly the 'dual dilemma', where the utilisation of dual is excluded in the presence of certain quantifiers. Discoveries derived from previous research on dual system in Tundra Nenets as well as outlook in this respect are demonstrated in the conclusion part.

\section{DIACHRONIC DEVELOPMENT OF TN DUAL SYSTEM}

\subsection{Dual in Proto-Uralic}

\subsubsection{Dual Marker for Nominal Declension}

According to Ánte, dual number can be reconstructed for Proto-Uralic possessive declension and verbal inflection, and is likely belonged to a subcategory of nominal number [7]. However, Ánte claims that the reconstruction of nominal dual markers remains problematic, since dual as a grammatical subcategory can only be found in Samoyed, Khanty, Mansi and Saami languages, and unambiguous reflexes of the nominal dual suffix $*-k(V)$ are only found in

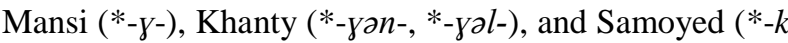
əń-) [7]. The Proto-Uralic nominal dual marker is $*_{-} k(V)$ [7].

Janhunen states that dual suffixes in Tundra Nenets consist of a person morpheme (the pronoun root) and a number marker [8]. Janhunen reconstructs the possessive dual suffix as ? $*_{-j}$ [n [8]. A similar version of Proto-Uralic dual marker is suggested by Ánte [7]. As shown in Table 1 and Table 2, two alternatives of Janhunen's person morpheme preceding the dual marker 
with $\stackrel{a}{\text { or }} \ddot{a}$ have merged into $i$ in first and second person and $A$ in third person in Ánte's paradigm. The archiphoneme $A$ represents the allomorph position $a$ versus $\ddot{a}$, or the front or back variant of open vowel $a$; the phonemical realisation of $A$ depends on the stem type that indicates means of vowel harmony [7]. For genitive, the initial nasal is $n$ in Janhunen's reconstruction, whereas $m$ stands in Ánte's version.

Table 1. Proto-Uralic dual possessive suffixes, raised by Janhunen

\begin{tabular}{|c|c|c|c|}
\hline & Absolute & $\begin{array}{c}\text { Genitive \& } \\
\text { Oblique }\end{array}$ & Accusative \\
\hline 1DU & $\begin{array}{c}?-m a ̊ j n /- \\
\text { mäjn }\end{array}$ & -nåjn/-näjn & -måjn/-mäjn \\
\hline 2DU & $?$-tåjn/-täjn & -ntåjn/-ntäjn & -mtåjn/-mtäjn \\
\hline 3DU & ? -såjn/-säjn & -nsåjn/-nsäjn & -msåjn/-msäjn \\
\hline
\end{tabular}

Table 2. Proto-Uralic dual possessive suffixes raised by Ánte

\begin{tabular}{|c|c|c|c|}
\hline & Nominative & Genitive & Accusative \\
\hline 1DU & ${ }^{*}-m i(j) n$ & ${ }^{*}-m i(j) n$ & ${ }^{*}-n i(j) n$ \\
\hline 2DU & ${ }^{*}-t i(j) n$ & ${ }^{*}-m t i(j) n$ & ${ }^{*}-n t i(j) n$ \\
\hline 3DU & ${ }^{*}-s A(j) n$ & $\begin{array}{c}{ }^{*}- \\
m s A(j) n\end{array}$ & ${ }^{*}-n s A(j) n$ \\
\hline
\end{tabular}

\subsubsection{Dual Marker for Verb Inflection}

Apart from use in the possessive, the dual marker *(j) $n$ also denotes subject personal endings on verbs [7]. Ánte argues that the Proto-Samoyed third person dual suffix in the indefinite conjugation $*_{-} k \partial \dot{n}^{\prime}$ is homonymous with the nominal dual marker, which can be interpreted as two separate dual markers $*_{-} k(V)$ and $*_{-}(j) n$ [7]. Ánte finds it quite necessary to date back to Proto-Uralic verb conjugation in regards to the combined suffix [7]. Ánte's Proto-Uralic verb inflection paradigm (see Table 3) incorporates default/indefinite and definite cases, while there is a relatively general interpretation by Janhunen (see Table 4).

Table 3. The subject person suffixes of Proto-Uralic verbs. raised by Ánte

\begin{tabular}{|c|c|c|}
\hline & $\begin{array}{c}\text { Default / } \\
\text { Indefinite? }\end{array}$ & Definite? \\
\hline 1DU & ${ }^{*}-m i(j) n$ & $?^{*}-m i(j) n$ \\
\hline 2DU & ${ }^{*}-t i(j) n$ & $?^{*}-t i(j) n$ \\
\hline 3DU & $?^{*}-k A(j) n$ & $?^{*}-s A(j) n$ \\
\hline
\end{tabular}

Table 4. Proto-Uralic verbal personal endings, raised by Janhunen

\begin{tabular}{|c|c|}
\hline $\begin{array}{c}\text { Person \& } \\
\text { Number }\end{array}$ & Form \\
\hline 1DU & $?$-måjn/-mäjn \\
\hline 2DU & $?$-tåjn/-täjn \\
\hline 3DU & $-k ə(-)$ \\
\hline
\end{tabular}

\subsubsection{Dual Personal Pronoun}

The presence of dual personal pronouns in ProtoUralic has been in doubt. Hajdú argues that the dual form of Proto-Uralic personal pronoun is unable to be reconstructed due to the diversity of formation of dual personal pronoun and other reasons [9]. A similar view is proposed by Kulonen, who believes in the shortage of evidence for reconstruction [10]. With more thorough research into this controversial point, the incapability of reconstructing dual personal pronouns in Proto-Uralic does not seem absolute but potential routes are proposed. Janhunen also acknowledges that it remains uncertain whether dual pronouns ever existed, but some evidence points to the possibility that Proto-Uralic pronouns may have been formed by attaching specific pronominal dual formatives to plural stems [8]. Ánte suggests that dual personal pronouns cannot be reconstructed, but their existence seems quite possible due to the role of dual number as a category of both nominal and verbal morphology in Proto-Uralic [7].

Hajdú states that Proto-Uralic personal pronouns are usually reconstructed from the basic form 1 . *me, 2.*te, 3. *se, the dual and plural personal pronouns derive from the basic form [9]. According to Janhunen and Honti, dual personal pronouns are reconstructed as 1 . *men, 2. *ten, 3. *sen [7, 8]. In addition to the demonstrative pronoun with the sound form *se, an alternative form $*_{s o}$ could also have existed (also for $* t \ddot{a} \sim * t o$ ). This could have induced the vowel change $* e$ $>*_{o}$ in the earlier dual pronouns *men, *ten $>*_{m o n}$, *ton [11].

\subsubsection{Restricted Use of Dual}

Janhunen holds the view that the reconstruction of Proto-Uralic dual system is difficult due to limited distribution of the dual [8]. Based on the analysis, it is pointed out that the dual nowadays only exists on the peripheries of the language family (Sami, Ob-Ugric, Samoyedic). Besides, the Proto-Uralic dual suffix has been materially only preserved in the eastern groups (Ugric, Samoyedic), which suggests that the use of the dual in Proto-Uralic was dialectally restricted [8]. The possessive declension in the present-day Uralic languages demonstrate various deviations from the reconstructed Proto-Uralic [8]. Hence, there are 
considerable obstacles in unifying underlying similarities and tracking back to the previous version. The individualising function of the number morpheme was probably more distinct in the dual, and the use of the suffix may have tended to be restricted to nouns semantically marked "+animate" or "+human" [8]. Thus, it is hard to say that dual system functions as a stable and well attested element in the Proto-Uralic morphological framework.

\subsection{Dual in Proto-Samoyedic}

Proto-Samoyedic retained the Proto-Uralic markers for the dual number [12]. The nominative dual suffix in Proto-Samoyedic absolute declension is *-ka'n (-kań in Mikola's 1988 version), which has developed into $-\chi V$ ', $-k(a)^{\prime}$ in Tundra Nenets and has also become the dual suffix in genitive and accusative [13, 14]. In the possessive declension, the dual marker is $*_{-} k^{\prime}{ }^{\prime} j-\left(*_{-} k V j\right.$ in Mikola's 1988 version), which all modern Samoyedic languages but Kamas take as their dual suffixes [13, 14]. Mikola states that singular nominative case is considered independently from others, since there is an evident difference in the second person suffix: singular nominative form -liń/-riń and non-singular-nominative form -tin, the latter follows the third person suffix form in both cases (see Table 5) [13]. In 2004, Mikola proposes the Proto-Samoyedic verb inflection paradigm (see Table 6), where the Proto-Uralic indeterminate conjugation third person dual suffix *-ka'n- shifts to $\chi V^{\prime},-k a$ ' in modern Tundra Nenets, and the counterpart in the determinate conjugation transforms from ProtoSamoyedic -tiń to Tundra Nenets - $d^{\prime} i$ ' [14]. Salminen suggests that the modern Tundra Nenets $i$ in dual suffixes (e.g., xalyaryih 'your (DU) fish (SG)'; me $e^{\circ}$ yih 'you (DU) are') appears to reflect a single PS $* i$ as well, although here its preservation must be attributed to analogy based on preterite forms where the vowel would have been stressed, e.g., me ${ }^{\circ}$ yincy ${ }^{\circ}$ 'you (du) were' < PN *meyatyinsya [15].

Table 5. Proto-Samoyedic dual possessive declension

\begin{tabular}{|c|c|c|}
\hline $\begin{array}{c}\text { Case \& } \\
\text { Nominative }\end{array}$ & Person & Form \\
\hline \multirow{3}{*}{ SG.NOM } & 1. & -miń \\
\cline { 2 - 3 } & 2. & -liń/-riń \\
\cline { 2 - 3 } & 3. & - -tiń \\
\hline \multirow{3}{*}{ Other cases } & 1. & -miń \\
\cline { 2 - 3 } & 2. & -tiń \\
\cline { 2 - 3 } & 3. & -tiń \\
\hline \multicolumn{2}{|c|}{ Dual marker: $-k V j-$} \\
\hline
\end{tabular}

Table 6. Proto-Samoyedic verbal suffixes

\begin{tabular}{|c|c|c|c|c|}
\hline & & Indet. & Indet.-Det & Det. \\
\hline \multirow{3}{*}{$\begin{array}{c}\text { All moods } \\
\text { except } \\
\text { imperative }\end{array}$} & 1. & & -miń & \\
\hline & 2. & & -riń, -liń & \\
\hline & 3. & $-k \partial ’ n ́$ & & -tiń \\
\hline \multirow[t]{2}{*}{ Imperative } & 2. & & -riń, -liń & \\
\hline & 3. & -jåkåń & & $-m t i n ́$ \\
\hline
\end{tabular}

\subsection{Dual in Nenets}

Personal endings in pre-Proto-Nenets shows a greater resemblance to suffixes in modern Nenets, including Tundra Nenets and Forest Nenets. Janhunen argues that the second person dual nominative ending in the possessive set denotes a morphophonological alternation from $*_{-} t$ to $*_{-} r$ [12]. Except the predicative third person dual ending $*_{-k}-\tilde{n}$, other endings follow the suffix pattern 1. $-m i-\tilde{n}$ 2. $-t i-\tilde{n}$ 3. $-t i-\tilde{n}$ as listed in Table 7 . Unlike in singular and plural endings, there is no suffix for the dual number in the reflexive subcategory, hence it is not shown in Table 7. Hajdú proposes paradigms of modern Nenets languages, indicating that the dual approached farther towards contemporary use as shown in Tables. 8 and 9 [16]. Nenets personal pronouns are presented as following: 1. mańi? 2. pidarí? 3. pid'i?.

Table 7. The system of personal endings in pre-protoNenets, raised by Janhunen

\begin{tabular}{|c|c|c|c|c|c|}
\hline & \multirow{3}{*}{$\begin{array}{c}\text { Predicati } \\
\text { ve }\end{array}$} & \multicolumn{4}{|c|}{ Possessive } \\
\hline & & \multicolumn{3}{|c|}{ SG } & \multirow{2}{*}{ DU-PL } \\
\hline & & NOM & ACC & OBL & \\
\hline 1. & ${ }^{*}-m i-\tilde{n}$ & ${ }^{*}-m i-\tilde{n}$ & ${ }^{*}-\varnothing-m i-\tilde{n}$ & ${ }^{*}-\varnothing-n i-\tilde{n}$ & ${ }^{*}-n i-\tilde{n}$ \\
\hline 2. & ${ }^{*}-t i-\tilde{n}$ & ${ }^{*}-r i-\tilde{n}$ & ${ }^{*}-m-t i-\tilde{n}$ & ${ }^{*}-n-t i-\tilde{n}$ & ${ }^{*}-t i-\tilde{n}$ \\
\hline 3. & ${ }^{*}-k \varnothing-\tilde{n}$ & ${ }^{*}-t i-\tilde{n}$ & ${ }^{*}-m-t i-\tilde{n}$ & ${ }^{*}-n-t i-\tilde{n}$ & ${ }^{*}-t i-\tilde{n}$ \\
\hline
\end{tabular}

Table 8. Nenets absolute declension, raised by Hajdú

\begin{tabular}{|c|c|c|}
\hline & Stem type 1 & Stem type 2 \\
\hline 1. & $-m^{\prime} i ?$ & $-m^{\prime} i ?$ \\
\hline 2. & $-r^{\prime} i ?$ & - l'i? $^{\prime}$ \\
\hline 3. & $-d^{\prime} i ?$ & $-t^{\prime} i ?$ \\
\hline
\end{tabular}


Table 9. Nenets verb conjugation, raised by Hajdú

\begin{tabular}{|c|c|c|c|}
\hline \multirow{2}{*}{\multicolumn{2}{|c|}{ Intrans.-indet. }} & 1. & -ńi? \\
\hline & & 2. & $-d^{\prime} i ?$ \\
\hline & & 3. & $-x V ?$ \\
\hline \multirow{6}{*}{ Determ. } & \multirow{3}{*}{$\begin{array}{c}\text { with SG } \\
\text { object }\end{array}$} & 1. & $-m^{\prime} i ?$ \\
\hline & & 2. & -rí? \\
\hline & & 3. & $-d^{\prime} i ?$ \\
\hline & \multirow{3}{*}{$\begin{array}{l}\text { with DU-PL } \\
\text { object }\end{array}$} & 1. & -ńi? \\
\hline & & 2. & $-d^{\prime} i ?$ \\
\hline & & 3. & $-d^{\prime} i ?$ \\
\hline \multirow{3}{*}{\multicolumn{2}{|c|}{ Reflexive }} & 1. & -ńi? \\
\hline & & 2. & $-d^{\prime} i ?$ \\
\hline & & 3. & $-x V ?$ \\
\hline
\end{tabular}

\section{MORPHOLOGY OF TN DUAL SYSTEM}

\subsection{Dual in Nominal Declension}

\subsubsection{Possessive and Non-Possessive Dual Marker}

In Tundra Nenets, the dual marker is $-x^{\circ} h$ in nonpossessive forms, -xəyu- in possessive forms, followed by possessive affixes [1]. Salminen also emphasises that the form of possessive dual marker -xəyu is different from the absolute dual marker $-x ə h$ [2]. The dual object substem, which is used in the objective conjugation when the object is dual, is formed by adding - xəyu- to the general finite stem, e.g., xada- ('to kill') > xadangax $x^{\circ} y u d a$ (indicative, object agreement with dual subject and third person singular object) [2]. According to Tatevosov, the Cyrillic interpretation of the suffix would be -хаю- [17]. Kröhnert suggests that possessive dual marker - $x ə y u$ - should be treated as a personal suffix instead of a sub-stem [18]. A formula is presented for a clearer understanding of the position and grammatical role of dual marker in an agglutinated gloss: [stem Root + $[$ Sub-stem(Mood) $]]+[$ Personal suffixes $(x ø y u)][18]$.

\subsubsection{Distinct Feature of Dual Possessive Suffix}

There are two sets of possessive suffixes in Tundra Nenets, one in singular and another shared by dual and plural [19]. In the first person possessive, a common suffix for all grammatical cases (nominative, accusative, genitive) is used: $-x \partial y u-n^{\circ}[1]$. In the second and third person possessive, the genitive suffix is different from its nominative and accusative counterpart due to a phonological alternation: the second singular nominative/accusative possessive ending $-t^{\circ}$ is voiced as $-d^{\circ}$ in postvocalic positions; in genitive. However, the suffix follows the genitive marker $-q-$, which yields the underlying sequence $-q t^{\circ}$ (see Table 10) [1]. Such morphophonological phenomenon is recognised by Salminen as "co-affixation": the non-nasalisable glottal stop $q$ appears as a preobstruental sandhi variant in dual forms in genitive and local cases, which serves as a crucial factor for the combination of co-affix and person $t$, constituting an underlying $q t$ [2]. Salminen argues that there is only one suffix $t$ in the third person inflection, while $d$ is regarded as a phonological sandhi variant [2].

Table 10. Dual possessive suffixes (partial), raised by Nikolaeva

\begin{tabular}{|c|c|c|c|}
\hline & Non- & \multicolumn{2}{|c|}{ Possessive } \\
\hline & Possessive & 1SG & $2 S G$ \\
\hline $\mathrm{NOM}$ & \multirow{3}{*}{ рәnо- $x^{\circ} h$} & \multirow{3}{*}{$\begin{array}{c}\text { пәпо-хәуu- } \\
n^{\circ}\end{array}$} & \multirow{2}{*}{$\begin{array}{c}\text { пәпо-хәуu } \\
\boldsymbol{d}^{\circ}\end{array}$} \\
\hline $\mathrm{ACC}$ & & & \\
\hline GEN & & & $\begin{array}{c}\text { пәпо-хәуu- } \\
\boldsymbol{t}^{\circ}\end{array}$ \\
\hline
\end{tabular}

\subsubsection{Dual in Local Cases}

Mikola argues that local cases (dative, locative, ablative, prosecutive) are expressed by the attachments of postpositions in the northern Samoyedic languages [14]. There is firm consensus among Samoyedologists that the grammatical cases (nominative, accusative, genitive) can combine with all three numbers, while the local cases are only used in singular and plural number. The missing local dual forms are replaced by periphrastic expressions with the corresponding case forms of the postposition nya- 'at', which is preceded by the genitive dual form of the relevant noun [1, 2, 20-23]. Local dual expressions are constructed by attaching respectively the case ending to the postposition nya (dative: $-h$; locative: $-n a$; ablative: $-d^{\circ}$; prosecutive: $m n a$ ), yielding a series of inflected form of postposition nya (dative: nyah; locative: nyana; ablative:.nyad ${ }^{\circ}$; prosecutive: nyamna), and finally adding it to the relevant word (an example in Table 11). An example is presented in Table 11:

Table 11. Dual declension of $t i$ 'reindeer', raised by Ackerman

\begin{tabular}{|c|c|c|}
\hline \multirow{3}{*}{$\begin{array}{c}\text { Grammatical } \\
\text { Case }\end{array}$} & NOM & tex $^{\circ} \mathrm{h}$ \\
\cline { 2 - 3 } & ACC & tex ${ }^{\circ} \mathrm{h}$ \\
\cline { 2 - 3 } & GEN & tex ${ }^{\circ} \mathrm{h}$ \\
\hline \multirow{2}{*}{ Local Case } & DAT & tex ${ }^{\circ}$ nyah \\
\cline { 2 - 3 } & LOC & tex ${ }^{\circ}$ nyana \\
\hline
\end{tabular}




\begin{tabular}{|l|c|c|}
\hline & $\mathrm{ABL}$ & tex $^{\circ}$ h nyad \\
& & \\
\cline { 2 - 3 } & PROS & tex \\
& & \\
\hline
\end{tabular}

Alternatively, Ackerman presents the structure of local dual case as a nominal lexeme $\mathrm{L}$ with feature values [NUMBER: dual], [CASE: $<\alpha$ : set of local cases>] having the exponence genitive stem form of $\mathrm{L}+\alpha$ case form of nya [23]. The earliest orthographic representation of local dual forms by Castrén attached the postposition to the core word, yielding one gloss, yet a blank space is left between the head noun and postposition in later interpretations, probably denoting the independent position of postposition nya. Nevertheless, such local dual forms have its restriction regarding the noun declension subcategory the word is subjected to. Nikolaeva holds the view that such a postpositional construction with nya-cannot be used in all syntactic contexts which require the use of local case forms. It is generally impossible in indefinite noun declension, because the dual marking is associated with definiteness [1]. For the indefinite case, though, numeral syidya 'two' is used to express the notion of two objects or people (discussed in details in Chapter 4) [1]. It is also of great necessity to emphasise the morphological function of postposition nya and the absence of grammatical directionality or semantic interpretation when used in local dual forms. In this case, Nikolaeva suggests that postposition nya- merely works as a periphrastic case expression and a distinct phonological word in terms of stress assignment and segmental phonology [1]. According to the results, the case forms of this postposition are also applied in various functions, with locational, temporal and abstract meaning by their own, and not necessarily with dual objects [1].

\subsection{Dual in Verbal Inflection}

As for subject agreement, two kinds of conjugation can be recognised: subject conjugation and reflexive conjugation. While the subject conjugation is primarily meant for intransitive verbs, reflexive conjugation aims at reflecting the inflectional forms of verbs of reflexive property. Salminen argues that in the number suffixation, which is used in the verbal inflection, the dual suffix is $-y i h$, where $y$ denotes the obligatory palatalisation of the preceding consonant [2]. In Castrén's orthographic representation, palatalisation is implicitly expressed in the combination of double consonant denoting possession and suffix -i', e.g., numm 'my God' > nummi' (first person dual); harr 'your knife' > harri' (second person dual) [20]. Both subject conjugation and reflexive conjugation in dual number share the ending series, which serves as the output of merge between possession marker and dual suffix -yih for the first and second person, and a separate for the third person: 1. -nyih 2. -dyih 3. $-x^{\circ} h$.
Object agreement is regarded as the inflection paradigm for transitive verbs, whose number and person should be in alignment with subject and number in agreement with object, yielding 27 output inflected forms. When considering a dual subject and object with any number, there are 9 inflected forms that all end with the mentioned palatalised suffix $-y i h$. Object agreement dual and plural object forms denoting plural subject share the same endings, preceded by dual marker -xəyuor plural marker $-y^{\circ}{ }^{-}$. Table 12 includes all object agreement suffixes under the dual subject condition (morphophonological processes not executed here):

Table 12. Object agreement with dual subject, raised by Hajdú

\begin{tabular}{|c|c|c|}
\hline Number & Person & Form \\
\hline \multirow{3}{*}{ SG } & 1. & $-m-y i h$ \\
\cline { 2 - 3 } & 2. & $-r-y i h$ \\
\cline { 2 - 3 } & 3. & $-d-y i h$ \\
\hline \multirow{3}{*}{ DU } & 1. & $-x ə y u-n-y i h$ \\
\cline { 2 - 3 } & 2. & $-x ə y u-d-y i h$ \\
\cline { 2 - 3 } & 3. & $-x \partial y u-d-y i h$ \\
\hline \multirow{3}{*}{ PL } & 1. & $-y^{\circ}-n-y i h$ \\
\cline { 2 - 3 } & 2. & $-y^{\circ}-d-y i h$ \\
\cline { 2 - 3 } & 3. & $-y^{\circ}-d-y i h$ \\
\hline
\end{tabular}

Dual suffixes in Tundra Nenets verbal inflection have been put into interpretations that are different in orthography or diacritics but accordant in their real morphophonological representations (see Table 13). While Tereshchenko and some Samoyedologists from the former Soviet Union apply the Cyrillic writing system, others are accustomed with the Latin one. For the palatalisation Salminen attaches $-y$ to the consonant, whereas Hajdú introduces consonants marked with acute $\left(m^{\prime}\right)$ or add an apostrophe $\left(d^{\prime}\right)$ to it. The underlying palatalisation in Tereshchenko's paradigm is embedded $\mathrm{C}+u$ palatalisation pattern that frequently appears in Russian. Salminen uses $h$ for word-final glottal stop, Hajdú relies on the IPA (International Phonetic Alphabet) marker ?, and Tereshchenko adds an apostrophe 'in the final position.

Table 13. Different representations by Tereshchenko, Salminen and Hajdú, summarised by Körtvély

\begin{tabular}{|c|c|c|c|c|}
\hline \multicolumn{2}{|c|}{} & $\begin{array}{c}\text { Tereshchen } \\
\text { ko } \\
(1965)\end{array}$ & $\begin{array}{c}\text { Salminen } \\
(1997)\end{array}$ & Hajdú \\
(1968)
\end{tabular}




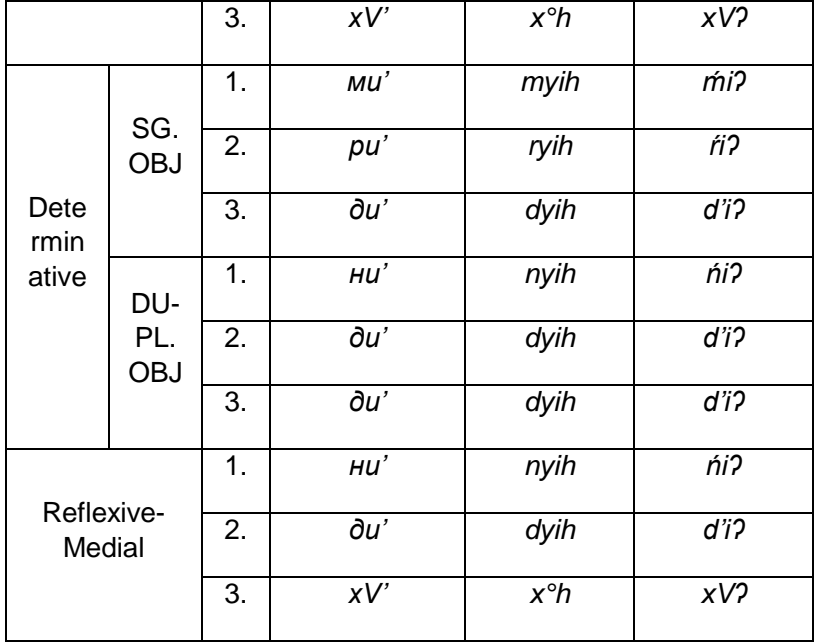

Personal suffixes in optative take another paradigm (see Table 14). Only the third person is considered in this inflection pattern, and the dual form is formed by combining an optative-specific suffix and the ending in subject/object agreement form, with the reflexive optative form an exception.

Table 14. Personal suffixes in optative, raised by Salminen

\begin{tabular}{|c|c|c|}
\hline \multicolumn{2}{|c|}{$\begin{array}{c}\text { Type of } \\
\text { agreement } \\
\text { (Number) }\end{array}$} & Form \\
\hline \multicolumn{2}{|c|}{ Subjective } & $-\ddot{y} a-x ə h$ \\
\hline \multirow{3}{*}{ Objective } & SG & $-\boldsymbol{m}-t-y i h$ \\
\hline & DU & \multirow{2}{*}{$-t ə-m-t-y i h$} \\
\hline & $\mathrm{PL}$ & \\
\hline \multicolumn{2}{|c|}{ Reflexive } & $-x \partial-m-t-t \partial q$ \\
\hline
\end{tabular}

The dual object substem is constructed by attaching - $x$ əyu - to the modal substem -- just as mentioned in 3.1 .1 -- in moods other than indicate, imperative and optative, e.g., xada- 'to kill': xadasax ${ }^{\circ} y u d a$ (indicative, object agreement with dual subject and third person singular object) [2].

\subsection{Dual in Pronouns}

Dual personal pronouns resemble the inflected dual endings in the object agreement as displayed in Table 15. There are some differences though: the affix of the first person nominative form is initiated with dentalalveolar $n$ instead of labial $m$; the second and third person genitive suffixes demonstrate a voiceless $t$. Castrén hints at the conclusion by stating that the dual and plural forms were created in an analogue way [20]. The commonality of dual and plural inflected patterns versus singular forms in the object agreement paradigm is also evident here in personal pronouns, indicating that the use of dual in Tundra Nenets and farther in Samoyedic or other Uralic languages might play a potential auxiliary role derived from the plural number.

Table 15. Singular and dual personal pronouns, raised by Salminen

\begin{tabular}{|c|c|c|c|}
\hline & & Singular & Dual \\
\hline \multirow{3}{*}{ NOM } & 1. & məny ${ }^{\circ}$ & mənyih \\
\hline & 2. & pider $^{\circ}$ & pid ${ }^{\circ}$ ryih \\
\hline & 3. & pida & pidyih \\
\hline \multirow{3}{*}{$\mathrm{ACC}$} & 1. & syiqm $^{\circ}$ & syid ${ }^{\circ}$ nyih \\
\hline & 2. & syit $^{\circ}$ & syid $^{\circ}$ dyih \\
\hline & 3. & syita & syid $^{\circ}$ dyih \\
\hline \multirow{3}{*}{ GEN } & 1. & syiqn $^{\circ}$ & syid $^{\circ}$ qnyih \\
\hline & 2. & syit $^{\circ}$ & syid $^{\circ}$ tyih \\
\hline & 3. & syita & syid $^{\circ}$ tyih \\
\hline
\end{tabular}

Salminen proposes that the basic reflexive stem in the person/number paradigm is xarq- [2]. Dual reflexive pronouns are formed by combining the reflexive stem and the unvoiced suffix used in the object agreement: 1 . xarnyih 2. xardyih 3. xardyih.

Mus suggests that the purely agglutinative interrogative pronouns have both dual and plural forms, and the corresponding markers are attached to the pronominal interrogative words [28, 29]. The dual human interrogative pronoun in nominative, accusative and genitive is xibyaxa?, the non-human pronoun yamgexe?. Salminen and Mus points out that as in local dual forms in nominal declension, dual form of interrogative pronouns in local cases are expressed by the combination of postposition nya- 'at' with the corresponding local cases and the genitive form of pronoun [27, 29]. Dual interrogative pronouns in nominative, accusative and genitive are expressed by the same lexemes: human interrogative pronoun xibyaxa? and non-human yamgexe? [29]. Further, Mus acknowledges that dual forms of nouns quantified by interrogative quantifiers śan and śayok are not attested, and speculate that the nominal referents may be only possible in singular [29].

\section{SYNTAX OF TN DUAL SYSTEM}

\section{1. 'Dual Dilemma'}

There is widespread consensus over the fact that dual number is in general not necessary any more in the presence of an ordinal numeral referring to two entities, namely syidya. Nikolaeva argues that the use of dual 
number in Tundra Nenets is limited, as it is likely to be related with definiteness and/or discourse givenness [1]. She discriminates two means of expressing two entities: nouns in dual forms denote referents that are already mentioned from the previous context, while newly introduced referents in the text that represent two objects or persons are usually interpreted by a noun in the singular form quantified by the numeral syidya 'two' [1]. Such phenomenon is attributed by Castrén to his notion that dual number has not yet fully developed in its individual cases (with an exception of nominative) and is usually substituted by the use of numeral syidya and the appropriate case form of the quantified word $[20,21]$. Nikolaeva suggests that the rule also applies for quantificational adjectives, which precede the head and do not cause dual marking [1]. These adjectives include: yamkexəw 'some', syan ' 'how many, how much; some', syan ${ }^{\circ}$ xəwa 'some, a few, several', tyanyo 'few, little', xәnyayi ' what, which', xurka 'what kind', xurkaxərt $^{\circ}$ 'any, no kind', xurkaryi 'any, any kind', xusuwey 'each, every, all kind of', etc. [1].

Tereshchenko argues that the noun is usually singular in conjunction with the numeral syidya (as well as in conjunction with other numerals) [21]. Nikolaeva, however, points out that although the absence of dual on nouns quantified by numeral denoting 'two' is generally without doubt, the use of dual still depends on certain conditions [1]. Nikolaeva suggests that the head noun quantified by syidya can be in either singular or dual, although the former one is in most cases preferred. Besides, it is primarily on account of the adjective-like grammatical properties of numeral syidya [1]. The presence of dual markers on the head noun are likely to be decided by its referential features: when the quantified nouns refer to non-human inanimate entities, an absence of dual marking can be recognised the dual is optionally possible when the head nouns are animate non-human; with human head nouns it is nearly obligatory to apply dual marking [1]. In this respect, Nikolaeva holds the view that the numeral syidya itself can optionally stand in the dual, which corroborates her idea that syidya can share more similarities with adjectives and unlike other numerals [1]. Tereshchenko also suggests that it is to some extent common to find a noun with a dual marker along with the number word syidya 'two'. In this cases, the dual number is expressed both syntactically and morphologically [21]. There are even combinations in which not only the noun, but the numeral syidya itself, is in the dual form, although it would not be the case for other numerals [21]. As for the complications for the optional coexistence of dual marking and use of numeral syidya as respectively morphological and syntactic representation of the semantic meaning denoting two entities, this phenomenon is named as "dual dilemma".

\subsection{Dual Concord}

Nikolaeva comments that another adjectival property of the numeral syidya is that objects quantified by syidya can trigger object agreement without any additional indication of definiteness [1]. In the language of folklore this numeral may exhibit attributive concord in case and/or possessive features, just as regular adjectives, and combinations of numerals with nouns in the dual can be found, though it seems to be an infrequent phenomenon $[1,21]$. As Tereshchenko and Nikolaeva notice, dual concord is rare, probably due to the structural complexity of dual forms [1, 30]. Dual forms are also used when there are two homogeneous elements in a sentence, where each of the homogeneous element may have a dual form, expressing proximity or a close connection between them, e.g., Вэсакохо', пухуияха' мят тэвы' 'Не reached the plague of an old man and an old woman' (not the plague of two old men and two old women) [21]. Nikolaeva points out that dual concord in the attribute nominative is not widely accepted, e.g. ? yesya- $x^{\circ} h$ xidya- $x^{\circ} h$ (metal-DU cup-DU) 'iron cup' [1]. Based on the analysis, several postpositions possess dual forms in combination with plural or dual objects, but this is optional and also not acknowledged by all consultants, for example, tolə$x^{\circ} h$ yilax ${ }^{\circ} h$ (table-DU.GEN under.DU) 'under two tables' [1]. Furthermore, Nikolaeva suggests that if the head noun quantified by numeral syidya corresponds to the subject, the verb must take the dual form in the subject agreement, even if the subject is in the singular [1]. She adds that if the objects are topical and do not have extra implication of definiteness, the objects quantified by syidya 'two' trigger the agreement, which should stand in the dual form, regardless of the situation that the quantified object is in the singular [1].

\section{CONCLUSION}

In summary, this paper discusses Tundra Nenets dual system from both diachronic and synchronic perspective, covering various morphological, morphophonological and syntactic features where the dual number is involved. Tundra Nenets dual system is thoroughly considered in its historical development, patterns in nominal declension, verbal inflection and pronoun paradigms, along with several issues concerning agreement in syntax. Diachronic morphophonological changes in Proto-Uralic and its daughter Proto-Samoyedic are considered here as the prerequisite for the contemporary usage of dual in Tundra Nenets. The analogous status between dual and plural number is evident in various morphological aspects such as verbal inflection and construction of pronouns, which might further indicate that dual was a derivative of plural number. Deviation of dual number 
in the presence of numeral syidya 'two' as well as other quantifiers reveals evidence for 'dual dilemma' that in most of the cases requires either dual marker or the corresponding quantifier for denoting the meaning of 'two entities'. While there have been different orthographic interpretations for the paradigms of dual number in different conjugations and declensions, there is few controversy over their underlying grammatical representations, especially in the recent decades. Due to the limited scale, pragmatic features and dialectal differences related to the use of dual number in Tundra Nenets are not discussed here and hence await future discoveries. This paper may serve as a further reference of historical development and morphological processes of Tundra Nenets for Samoyedologists, researchers of dual system, and scholars in the relevant fields. By referring to a variety of characteristics of dual number in Tundra Nenets, this study provides new insights into this uncommon grammatical number that has been experiencing abundant variations, and calls for further attention to this interesting morphological and syntactic trait that may have great potential as a future research hotspot in the field of Uralic, Samoyedic, and Nenets studies. Overall, these results offer a guideline for diachronical, morphological and syntactic aspects of dual number studies in Tundra Nenets, and provide new insights into the research of dual system in Samoyedic languages.

\section{REFERENCES}

[1] Nikolaeva, I. (2014). A Grammar of Tundra Nenets. Berlin: De Gruyter.

[2] Salminen, T. (1997). Tundra Nenets inflection. Helsinki: Suomalais-Ugrilainen Seura.

[3] Corbett, G. G. (2000). Number (Cambridge textbooks in linguistics). Cambridge: Cambridge University Press.

[4] Klumpp, G., Mazzitelli L. F. \& Rozhanskiy, F. (2018). Typology of Uralic languages: Current Views and New Perspectives (Introduction to the special issue of ESUKA-JEFUL). ESUKA-JEFUL, $9,1,9-30$.

[5] Clackson, J. (2007). Indo-European Linguistics: An Introduction. New York: Cambridge University Press.

[6] Fritz, M. (2011). The Dual in Indo-Germanic Languages. Heidelberg: Universitätsverlag.

[7] Ánte, L. S. S. (2019). Proto-Uralic. In: Bakró-Nagy M., Laakso J. \& Skribnik E. (Eds.), The Oxford Guide to the Uralic Languages. Oxford University Press. https://www.academia.edu/40193033/ProtoUralic
[8] Janhunen, J. (1982). On the Structure of ProtoUralic. Finnisch-Ugrische Forschungen, 44, $23-42$.

[9] Hajdú, P. (1986). Second person pronouns in Uralic languages. Советское финно-угроведение, $22,1-8$.

[10] Kulonen, U. (2001). On the elements with $\mathrm{n}$ in second person pronouns of Ob-Ugric languages. Finnisch-ugrische Forschungen, 56, 151-174.

[11] Honti, L. (2012). The age and origin of the personal pronouns with velar vowels. Mémoires de la Société Finno-Ougrienne, 264, 121-129.

[12] Janhunen, J. (1998). Samoyedic. In Daniel Abondolo (Eds.), The Uralic languages (pp. 457479). London \& New York: Routledge.

[13] Mikola, T. (1988). History of Samoyedic Languages. In Denis Sinor (Eds.), The Uralic languages: description, history and foreign influences (Handbuch der Orientalistik 8: Handbook of Uralic studies 1, pp. 219-263). Leiden: Brill.

[14] Mikola, T. (2004). Studies of History of Samoyedic Languages (aus dem Nachlass herausgegeben von Beäta Wagner-Nagy). Szeged: SzTE FinnischUgrisches Institut.

[15] Salminen, T. (2012). Traces of Proto-Samoyed vowel contrasts in Nenets. Mémoires de la Société Finno-Ougrienne, 264, 339-358.

[16] Hajdú, P. (1988). The Samoyedic Languages. In Denis Sinor (Eds.), The Uralic languages: description, history and foreign influences (Handbuch der Orientalistik 8: Handbook of Uralic studies 1, pp. 3-40). Leiden: Brill.

[17] Tatevosov, S. (2016). Structure and interpretation of Tundra Nenets verbs: eventuality types and conjugational classes. Moscow: Bonpocbl языкознания, 2016, 3, 81-114.

[18] Kröhnert, H. (2010). Northern Samoyedic Verb Inflection between Phonology and Syntax: An Article in the Framework of Distributed Morphology. In Sebastian Bank, Doreen Georgi \& Jochen Trommer (Eds.), Linguistische Arbeitsberichte 88 (pp. 93-123). University of Leipzig.

[19] Jalava, L. (2013). “Adjectives" in Tundra Nenets: Properties of property words. Journal de la Société Finno-Ougrienne, 94, 37-67.

[20] Castrén, M. A. (1854). The Grammar of Samoyedic Languages (Published by Anton Schiefner). St. Petersburg: Buchdruckerei der Kaiserlichen Akademie der Wissenschaften. 
[21] Tereshchenko, N. M. (1947). A Study in the Grammar of the Nenets (Yurak Samoyedic) Language. Leningrad: Uchpedgiz.

[22] Künnap, A. (1982). Main Sources of Secondary Endings for Local Cases in Samoyedic Languages. Советское финно-угроведение, 18, 194-200.

[23] Ackerman, F. (2000). Lexical constructions: Paradigms and periphrastic expression [Conference Presentation]. Berkeley Formal Grammar Conference.

[24] Tereshchenko, N. M. (1965). Nenets-Russian Dictionary. Moskva: Sovetskaja Enciklopedija.

[25] Hajdú, P. (1968). Chrestomathy of Samoyedic Languages. Budapest: Tankönyvkiadó.

[26] Körtvély, É. (2005). Verb conjugation in Tundra Nenets. Szeged: Studia Uralo-Altaica.

[27] Salminen, T. (1998). Nenets. In Daniel Abondolo (Eds.), The Uralic languages (pp. 457-479). London \& New York: Routledge.

[28] Tereshchenko, N. M. (1959). A Help Book for the Self-study of Nenets: A Study in the Contrastive Nenets-Russian Grammar. Leningrad: Uchpedgiz.

[29] Mus, N. (2015). Interrogative words and content questions in Tundra Nenets. [PhD thesis, University of Szeged]. SZTE Repository of Dissertations. Retrieved from http://doktori.bibl.uszeged.hu/id/eprint/2764/1/Con tent_questions_in_TN_Nikolett_Mus_2015_06.pdf

[30] Tereshchenko, N. M. (1973). The Syntax of Samoyedic Languages: The Simple Clause. Leningrad: Nauka. 